\title{
A Review of White Mango Scale (Aulacaspis tubercularis Newstead; Hemiptera: Diaspididae) in Sub-Saharan Africa: Distribution, Impact and Management Strategies
}

\section{Hillary M.O. Otieno}

Department of Plant Science and Crop Protection, University of Nairobi, Nairobi.

Abstract | White mango scale (Aulacaspis tubercularis Newstead) pest is threatening mango production in Sub-Saharan Africa (SSA). Being a new pest, there are no clear adaptable management practices ready for farmers to implement. This has caused farmers to rely on nature and sometimes adoption of crude and ineffective traditional control methods. Farmers capable of using pesticides apply very toxic products that are not only harmful to the applicators but also to the beneficial organisms. Agronomic management strategies like right varieties, spacing, better fertilization and shed management are also applied inappropriately. This review is therefore essential in providing the basis of identification of $A$. tubercularis. It also provides management strategies that could be adopted by mango farmers in the region. Last, it highlights key research themes worth prioritizing for better understanding and management of the pest in the region.

Received | August 25, 2020; Accepted | November 24, 2020; Published | March 06, 2021

*Correspondence | Hillary M.O. Otieno, Department of Plant Science and Crop Protection, University of Nairobi, Nairobi; Email: hillarymoo@ yahoo.com

Citation | Otieno, M.M.O., 2021. A review of white mango scale (Aulacaspis tubercularis Newstead; Hemiptera: Diaspididae) in Sub-Saharan Africa: distribution, impact and management strategies. Pakistan Journal of Agricultural Research, 34(1): 227-238.

DOI | http://dx.doi.org/10.17582/journal.pjar/2021/34.1.227.238

Keywords | Aulacaspis tubercularis, Integrated pest management, Mango production, Mango yield loss, Mango scale, Parasitoids and predators

\section{Introduction}

$\mathrm{M}$ ango (Mangifera indica L.) is one of the most produced horticultural fruit crops in the SubSaharan Africa region (SSA) with both economic and nutritional values. However, the production potential is yet to be fully realized due to constraints such as soil infertility, drought, diseases (e.g. powdery mildew and anthracnose), insect pests (e.g. thrips, fruit fly, termites, thrips, mango seed weevil, white mango scale), and poor agronomic practices (Griesbach, 2003; Yeshitila and Nessel, 2003; Kameri, 2012; Mulinge, 2015; Bazu et al., 2015). Among the pests, white mango scale (Aulacaspis tubercularis Newstead) has emerged to be an important pest affecting mango production in the world (Figure 1 ). A. tubercularis is believed to have originated from Asia (Borchsenius, 1966). The global dispersal of this pest could have occurred through the movement of plant parts. In Mexico, $A$. tubercularis has been named as the second most important mango pests after fruit flies (Anastrepha sp.; Diptera: Tephritidae) (Senasica, 2009). In SSA region, the pest has been reported in major mango-producing countries (Figure 1) causing considerable economic losses to producers (Michael et al., 2014; Hodges and Hamon, 2016; CABI, 2019). These losses vary from low to high depending on climate, variety, pest population and targeted market. For instance, in Kenya the impact is less serious and is not consider as an important pest by some mango farmers (Djirata et al., 2016); while in other countries like Ethiopia (Ofgaa and Emana, 2015), Egypt (Bakr 
et al., 2009), and South Africa (Le Lagadec, 2002) the pest is threatening production. The perceived low economic importance of this pest by some farmers (like in Kenya) could be because of the 'cosmetic' (pinkish blemish) damages on fruit skins (with no significant loss of physical yields) (Heriberto et al., 2016). This is especially true with farmers who are producing mangoes for local markets where buyers pay little attention to the physical appearance of the fruit skin cover. Although could be low in some countries damages, farmers in those areas have confirmed the incidences are on the rise and spreading (Djirata et al., 2016). In Ethiopia, A. tubercularis has emerged to be the second most important mango pest after anthracnose disease (Anjulo, 2019).

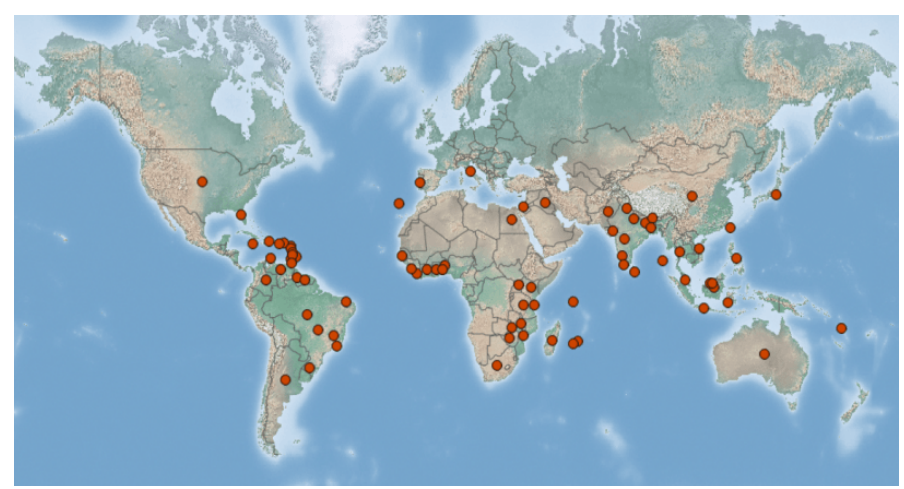

Figure 1: Global distribution map of White mango scale (A. tubercularis Nerwstead) pest, represented by the orange dots. Adapted from CABI, 2019.

Once present in a region, the pest spreads faster because of its small body size, which makes it easy to spread with fruits, seedlings, and even by the wind. This characteristic has made the pest to colonize most of the mango producing zones. Being an invasive pest, the information about the pest and its management practices is less available for researchers, policymakers, and farmers in the SSA region. In fact, most research work in the region has focused around assessing the distribution and population dynamics (Babege et al., 2017; Djirata et al., 2019; Teshale et al., 2019) with a few trying to answer questions around management practices (Abo-Shanab, 2012; Ayalew et al., 2015). The coverage of these type of research is narrow in the region, mainly in Ethiopia, Egypt, Kenya and South Africa. The research on management strategies seemed to be slow despite the speed at which the pest is spreading and the potential losses it could cause to the already resource-constrained farmers in the region. So the present investigation was to shed light on $A$. tubercularis insect pest in the region in terms of; (a) Understanding the life cycle, current distribution and impact of in the Sub-Saharan Africa region; (b) Assessing available integrated pest management practices for adoption by farmers.

\section{Data collection and review process}

The review focused on the Sub-Saharan Africa (SSA) region; hence top priority given to research work published in these targeted countries. These materials were searched online, downloaded, stored and read. The management strategies were classified into three categories, namely; cultural, biological and chemical strategies. On the use of pesticides, efficacy and human toxicity potentials were assessed. The toxicity potential of these chemical compounds were assessed using acute oral $\mathrm{LD}_{50}$ values. The acute oral $\mathrm{LD}_{50}$ values were extracted from the material safety data sheets (MSDS), World Health Organization database (WHO, 2019), Food and Agriculture Organization database (FAO, 2019), and Cornell University's Extension Toxicology Network database (EXTOXNET, 1993). The active ingredients were further classified based on their mode of action (MoA) as given by the Insecticide Resistance Action Committee (IRAC, 2019). The MoA of a product provides farmers and crop production advisors with useful information during selection and rotation of insecticides for effective and sustainable management of insecticide resistance (IRAC, 2019). The active ingredients were further assessed for their effects on the environment based on the Environmental Impact Quotient (EIQ) values of the compounds given by Eshenaur et al. (2019). The EIQ is a formula created to provide growers with data regarding the environmental and health effects of pesticide applications so they may make better informed decisions regarding their pesticide selection (Kovach et al., 1992). The EIQ values are calculated using the formula provided by Kovach et al. (1992);

\section{$E I Q=\left\{C\left[\left(D T^{*} 5\right)+\left(D T^{*} P\right)\right]+\left[\left(C^{*}((S+P) / 2) * S Y\right)+(L)\right]+[\right.$ $\left.\left.\left(F^{*} R\right)+\left(D^{*}((S+P) / 2) * 3\right)+\left(Z^{*} P^{*} 3\right)+\left(B^{*} P^{*} 5\right)\right]\right\} / 3$}

Where;

$\mathrm{DT}=$ dermal toxicity $\mathrm{C}=$ chronic toxicity; $\mathrm{SY}=$ systemicity; $\mathrm{F}=$ fish toxicity; $\mathrm{L}=$ leaching potential; $\mathrm{R}=$ surface loss potential; $\mathrm{D}=$ bird toxicity; $\mathrm{S}=$ soil half-life; $\mathrm{Z}=$ bee toxicity; $\mathrm{B}=$ beneficial arthropod toxicity and $\mathrm{P}=$ plant surface half-life

The lower the EIQ value, the better. Finally, the individual active ingredients were checked from the Pesticide Action Network International (PAN) 
consolidated list of banned pesticides (2019) for a ban in any country. The countries with a reported ban on a pesticide were counted and recorded. The PAN list was chosen because of its comprehensive and up-todate compilations across the world.

Lifecycle, current distribution and impact of white mango scale pest in the Sub-Sabaran Africa region

Pest distribution, description, life cycle and host plants in Sub-Saharan Africa: White mango scale (Aulacaspis tubercularis Newstead) is a sessile armored tiny shelled insect belonging to Order Hemiptera, Family Diaspididae (CABI, 2019). This insect family has been reported to have over 300 species, some of which are classified as pests (like $A$. tubercularis Newstead) (Urías-López et al., 2010). The biological cycle of $A$. tubercularis is highly influenced by the prevailing climatic conditions, mainly rainfall, temperature (Ofgaa et al., 2018) and sex (Arias et al., 2004). According to the Northern Territory Government of Australia (2019), the cycle takes 35-40 days in summer, 70-85 days in winter. In Ecuador, this cycle was reported to last about 52 days in females and 36 in males (Arias et al., 2004). This means that in a year, the pest could have 3-4 overlapping generations (Salem et al., 2015; Hamdy, 2016). Mature female white mango scale can lay 80200 eggs (Sayed, 2012). Of the hatched crawlers, about $80 \%$ usually become males (Van Halteren, 1970). After hatching, crawlers move to the feeding sites on the plants within 24 hours where the female crawlers settle randomly whereas male crawlers settle in groups close to females (Figure 2A) (Van Halteren, 1970). These crawlers are deep bright brick red. The female has circular, flat, thin and often wrinkled with opaque white shells while the male shells are small, rectangular and white with three raised longitudinal ridges and exuviae terminal (Figure $2 \mathrm{~B}$ and $2 \mathrm{C}$ ) (Moharum, 2012; Hodges and Hamon, 2016). The pest has piercing and sucking mouth part called stylet bundle- this is chitinous tube composed of 4 stylets, 2 maxillae and 2 mandibles, that interlock to form 2 canals, one for saliva (salivary canal) and one for sucking food (food canal) (Juárez-Hernández et al., 2019). During feeding, the stylet bundle is pushed through into the host parenchymal cells or vascular bundle tissues where the pest obtains the sap and injects toxins in the plant (Heriot, 1934; Sadof and Neal, 1993; Peña et al., 2009; Rehmat et al., 2011). According to Borchsenius (1966) and Malumphy (2014), A . tubercularis pest feeds on many plants belonging to about 18 species. These plants also play host and include Aceraceae (e.g. Acer kawakamii), Anacardiaceae (e.g. Mangifera indica, Mangifera sp.), Arecaceae (e.g. Cocos nucifera), Iridaceae (e.g. Dietes prolongata), Lauraceae (e.g. Cinnamomum camphora, Cinnamomum ceylanicum, Laurus nobilis, Litsea laurifolia, Litsea polyantha, Litsea pungens, Litsea sebifera, Machilus sp., Phoebe sp.), Pittosporaceae (e.g. Pittosporum glabratum), Rutaceae (Citrus sp.), and Sapindaceae (e.g. Dimocarpus longan). At any given time in the farm, the abundance of $A$. tubercularis insect pests is influenced by the presence and abundance of the predators, parasitoids, humidity and temperature (Mani and Krishnamoorthy, 1998).
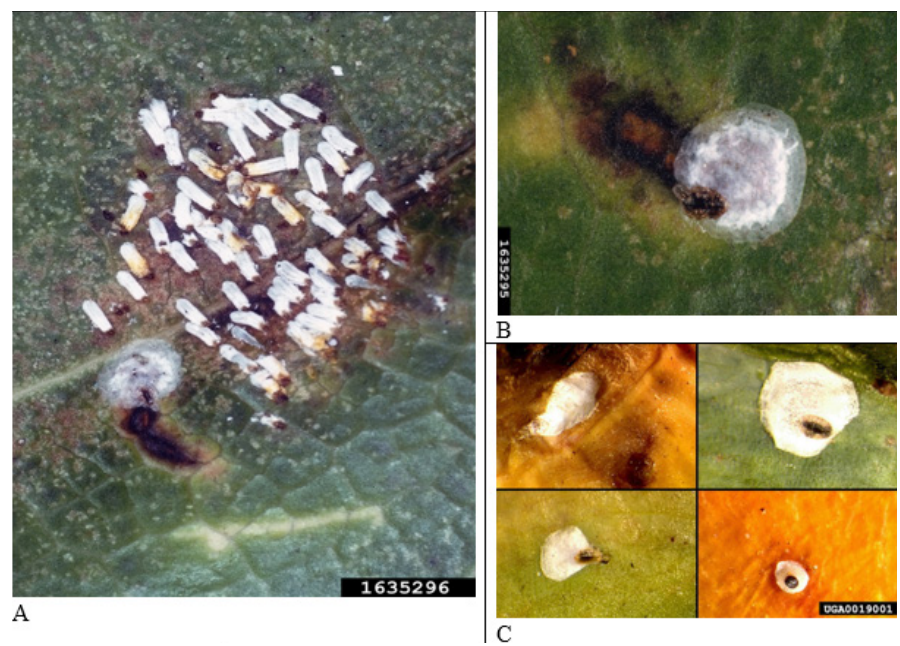

Figure 2: Mango white scale ( $A$. tubercularis): $A=$ A group of male covers with one female cover (lower right); $B=$ High resolution female white cover; $C=$ High resolution male and female white scale. Photo source: John W. Dooley, USDA APHIS PPQ, Bugwood.org.

Economic importance of A. tubercularis in Sub-Saharan Africa

White mango scale has spread and currently affecting mangoes in several countries in Sub Saharan Africa Ghana, Kenya, Madagascar, Mauritius, Mozambique, South Africa, Tanzania,Uganda,Zanzibar,Zimbabwe, Egypt, and Ethiopia (Figure 3). The economic impact of this pest could range from low to high depending on the targeted market (e.g. local versus international) and part of mango infested (e.g. seedling, leaves and fruits). For instance, in Kenya, the pest has been reported in most of the mango producing zones. However, some farmers (about 14\%) still do not know it nor consider it as a pest (Djirata et al., 2016). White mango scale pest spread so fast and is expected to be present throughout the year with high incidences at flowering and fruit maturation stages. In Ethiopia, the incidence was reported to vary between 40 and 100\% (Duressa, 2018). Once on the plant, they 
cause injuries through sucking of plant saps on leaves, branches, and fruits (Figure 4). Under heavy infestation, mango plants may experience chlorosis, defoliation, drying up of twigs, and poor blossoming leading to poor growth and development (Halteren, 1970). The impacts could be higher during hot and dry weather periods than during rainy periods especially on young seedlings and mango trees. On fruits, the pests cause premature fall of young and just set fruits while mature fruits develop pink blemishes that make them unappealing (cosmetic damage) leading to loss of market value especially at the international export markets (Labuschagne et al., 1995). The economic importance of this pest could also be looked at in terms of the cost of controlling it. In Kenya, farmers who use chemical methods are reported to be using about $13 \%$ of the total income generated from mango sales towards the control of this pest (Djarat et al., 2016). This cost is high and unsustainable considering the poor financial status of the smallholder producers. When comparing mango production before and after A. tubercularis emergence, Fita (2014) reported a significant reduction in fruit yields in five districts in Western Ethiopia. The population density of the pest positively influences the fruit yield losses. Bakry and Tolba (2018) reported that an increase of one white mango scale insect per leaf decreases fruit yields in the range of 1.31 to $4.28 \mathrm{~kg}$ per tree per year.

Integrated pest management strategies for $A$. tubercularis control in Sub-Saharan Africa region

The application of integrated pest management (IPM) strategy in the control of white mango scale involves integrating a range of plant protection methods that limit the development of populations of the pest while keeping the use of pesticides to levels that are economical and minimizes risks to human health and the environment. For sustainable management, farmers should be advised to adopt more than one practice.

Cultural and agronomic strategies: Both cultural and agronomic strategies are aimed at modifying the environment to reduce prevalence. A number of practices have been found effective and recommended for white mango scale insect control across the affected countries.

The first and most important strategy in dealing with crop pests and diseases is practicing proper field and variety selection selecting mango varieties with better tolerance and selecting fields with no or low pest incidences. However, existing land tenure systems and high subdivision as witnessed in the SSA region may not allow for proper field selection to be practiced adequately. Under such situations, farmers are advised to properly select mango varieties and plant tolerant types only. Based on research from Asia and Africa, Ataulfo, Apple, Haden, and Keit mango varieties have been reported to be more tolerant to white mango scale compared to other varieties such as Alphanso, Kent, Tommy Atkins and Dodo (UríasLópez et al., 2010; Djirata, 2017; Teshale et al., 2019). These tolerant varieties should therefore be promoted to help manage the looming danger of the pest in the region.

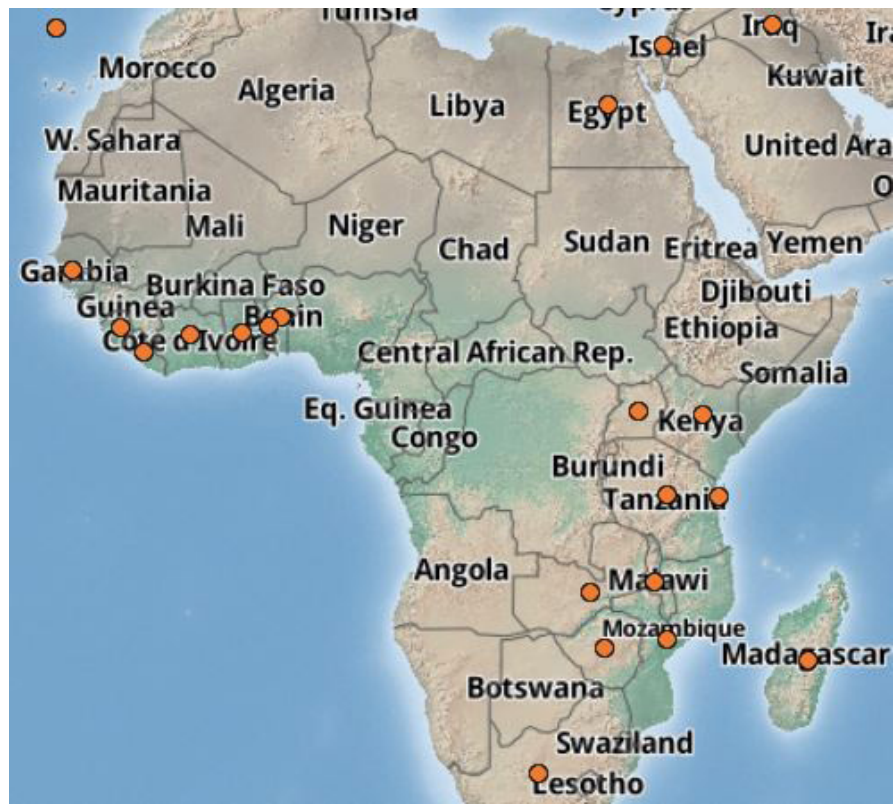

Figure 3: Africa distribution map of White mango scale (A. tubercularis Newustead) pest, represented by the orange dots. Adapted from: $C A B I, 2019$
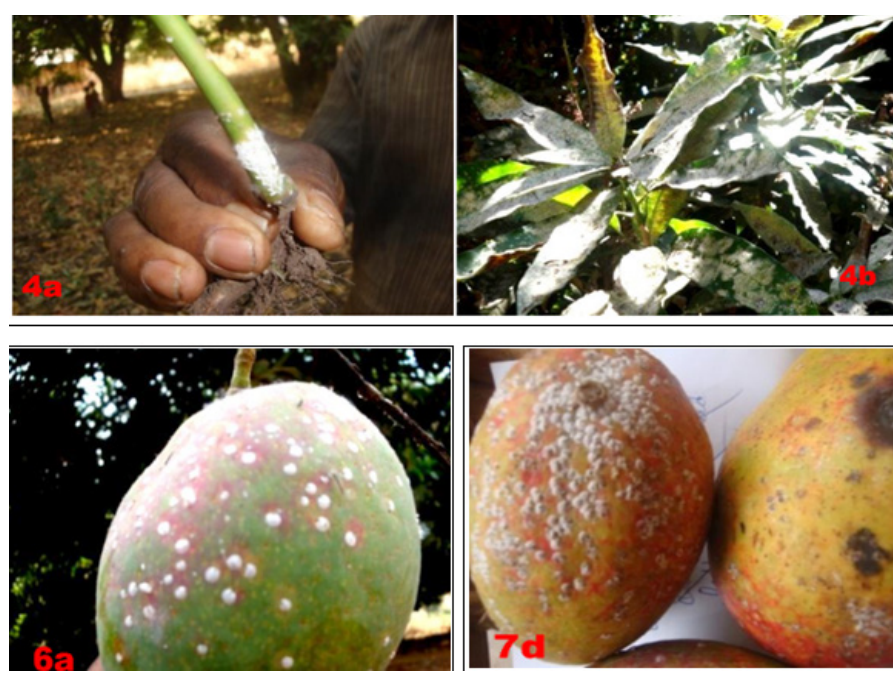

Figure 4: Damages caused by white mango scale on mango: $4 \mathrm{~A}$ : attack on mango seedling stem; $4 b$ : attack on mango leaves; $6 a$ and 7d: attack on mango fruits. Adapted from: Fita, 2014. 
Another important practice is by adopting better mango trees density. Optimum spacing ensures that plants do not compete for growth factors leading to better pest resistance. Again, avoiding crowded fields reduces the rate at which these pests spread. Currently, there is no consistency in the spacing used among farmers with others planting as narrow as 2 $\mathrm{m} \times 2 \mathrm{~m}$ leading to the high densities (Dessalegn et al., 2014; Neguse et al., 2019). Such high densities could also be encouraging breeding and survival of most of these damaging mango pests. Better mango tree spacing is influenced by climate, soil fertility and variety. According to Ngethe et al. (2019) spacing of $10 \mathrm{~m} \times 10 \mathrm{~m}$ in the dry zones and $12 \mathrm{~m} \times 12 \mathrm{~m}$ in wet and rich soils is recommended for the production of all grafted mango. Though, much smaller spacing of $8 \times 10 \mathrm{~m}$ could still be adopted for short stature varieties and wider spacing of $12 \times 14 \mathrm{~m}$ for extra tall and heavily shading varieties (Griesbach, 2003).

Proper and constant scouting and monitoring of pest populations is another important IPM strategy towards management of white mango scale pests. Monitoring is the process of searching and watching regularly for the appearance of white scale pests to help in early detection and control before causing injuries. White scale should be monitored fortnightly from flushing stage after mango harvesting (here, check on leaves) and when fruits are $1.5-2 \mathrm{~cm}$ across (here, check for both fruits and leaves) (Duressa, 2018). Though, it should be noted that the pest is expected to exist throughout the year once present in the field. These mango stages usually coincide with when crawlers have emerged and are very active. During the monitoring process, check 5 branches on each of 10 trees per hectare (Northern Territory Government of Australia, 2019). The control threshold is expected to vary depending on the climate, season (off season versus on-season of production) and market (local versus international market). However, control practice should be initiated when at least 20 individual pests are recorded per twig sampled (Camacho and Chong, 2015).

Pruning is another important practice that could be applied for the management of $A$. tubercularis pest. The practice involves cutting and removal of infested mango twigs with the aim of reducing pest population. The infested cut branches are then burned outside the farm. The annual pruning carried out at the end of every harvesting season effectively opens up the canopy for better air circulation and light penetration conditions that discourage multiplication of the pest. In Ethiopia, up to about $77 \%$ of mango farmers practice pruning and have reported improved management of $A$. tubercularis compared to the unpruned tree (Fita, 2014; Anjulo, 2019). Also, Bautista-Rosales et al. (2013) reported a significant $65 \%$ reduction in mango scale population due to pruning alone.

Smoking within the mango tree and use of organic concoctions are also among cultural practices currently used by local farmers. Smoking practice involves burning organic materials (e.g. dried grass, mango leaves, and animal dung, etc.) within the mango trees to produce a good amount of smoke to chase away insect pests without affecting important plant growth processes. To concentrate the effect within individual mango trees, smoke pots/ cans with holes at the bottom for air intake and containing burning organic materials mixed with repellent herbs (e.g. lemongrass) could be used (Infonet-Biovision: www.infonetbiovision.org). These pots are hung at strategic places within the mango tree to produce a good amount of smoke which chase insects away from the tree. Apart from driving away pests, the method has also been claimed to aid in good fruit setting (Infonet-Biovision: www.infonet-biovision.org). In Ethiopia, the practice is currently used by about $1.7 \%$ of mango farmers (Fita, 2014). The smoking method should be used cautiously to avoid causing burns on branches. Other farmers use locally prepared concoction made from soap, ash and goat urine mixtures, which are sprayed on the affected twigs (Terefe et al., 2014). Though claimed to have some level of efficacy capacity, these practices are farmers' own innovations with no proper scientific backing. Hence need further investigation to identify the best rates to be applied and when to make the applications to achieve a meaningful reduction of these scale insects.

Biological strategy: Biological strategy refers to the use of living organisms, usually natural enemies (e.g. parasites and parasitoids) to control $A$. tubercularis pest. These organisms exist naturally in the field, though can also be introduced or increased in population in an area. The method relies on mechanisms such as predation, parasitism and herbivory to control insect populations. Several natural enemies have been reported to be highly effective in the management of white mango scale. Examples of these natural 
enemies include Cybocephalus binotatus, Aphytis chionaspis, A. mytilaspidis, Encarsia citrine, Chilocorus, Scymnus syriacus, Sukunabikona prapawan, Rhyzobius pulchellus, $R$. lophanthae, Pteroptrix koebelei, and Aleurodothrips fasciapennis (Daneel and Dreyer, 1997; Mani and Krishnamoorthy, 1998; Abo-Shanab, 2012; Sayed, 2012; Hamdy, 2016; Djirata, 2017; CABI, 2019). Biological methods offer sustainable pest management because once introduced, the predators are capable of breeding and multiplying themselves in the farmer fields. In South Africa, a retrospective study of past Cybocephalus releases, trials carried out in insect-proof tents and large field trials revealed that the predators successfully controlled scale populations to levels of 2-3\% scale infestation (Le Lagadec, 2002). The author recommended these beetles to be released at a rate of 500-1000 beetles per hectare in order to achieve effective control of white mango scale insects.

Since these predators occur naturally, in the mango fields, farmers need to be careful and encourage their natural multiplication and survival. Use of pesticides is one of the main causes of high proliferation of A. tubercularis pests due to mass killing of these natural enemies (Viljoen and Villiers, 1987). To enable natural breeding, farmers should use narrowspectrum pesticide products that are only specific to the $A$. tubercularis insect pests. Alternatively, farmers could adapt alternate tree row spraying strategies to avoid mass killing and/or driving away predators out of the farms. This practice works by giving predators pesticide-free mango tree rows to survive while others are sprayed. Also, farmers could use attractants and nutritional supplements to increase mango white scale predators in the farms. Hernández-Fuentes et al. (2012) reported that application of methyl salicilate or water, yeast, sugar and powder milk mixtures attracted Ceraeochrysa spp. predator that significantly reduced $A$. tubercularis insect pest by $65-93 \%$.

Chemical strategy: Chemical method refers to the use of synthetic or organic compounds capable of killing Aulacaspis tubercularis. Application of these chemicals should be done with caution to minimize damages to the ecology. Current the use of pesticides in low in the region; in Ethiopia, only $21.5 \%$ farmers apply chemicals for the control of white scale (Ajulo, 2019). These applications are random and not based on any critical threshold; as farmers make applications decisions visually. This could be due to lack of control threshold provided by researchers in the region
(Mossler and Nesheim, 2004). This research reported a number of synthetic products that have been trialed with better outcomes and recommended for use in the control of $A$. tubercularis insect pest across affected countries (Figure 5). The reported efficacy vary from one research to the other depending on the stage of pest when application was made, the efficiency of the application process and the type of trial (laboratory versus field trial). Bi-weekly application of Movento and Methidathion 400EC pesticides was found to cause up to $90 \%$ and $74 \%$ mortality of white mango scale insects after the fifth round of applications respectively (Ayalew et al., 2015). Here, Movento product was recommended for use in the control of the pest. In another trial by Djirata (2017) on efficacy of two insecticides against white mango scale, control of up to $90 \%$ and $38 \%$ were recorded as a result of Folimat 500SL and closer 240SC pesticide applications respectively, after three application regimes (Figure 4). A laboratory trial of propylene glycol monolaurate and mineral oil pesticide active ingredients recorded $100 \%$ and $98 \%$ mortality of female white mangos scale respectively (Mendoza-Montero et al., 2017). Other products have also been trialed: Applaud 25\% SC, Karate $2.5 \%$ EC and Agrothion 57\% pesticides recording average mortalities of $76.1 \%$ (highest mortality $=97.8 \%), 73.53 \%$ (highest mortality= $98.7 \%$ ) and $68.6 \%$ (highest mortality $=96.1 \%$ ) of $A$. tubercularis insect pest, respectively (Figure 5) (Salem et al., 2011).

The use of oil-based products is also taking shape and has been trialed in open and closed fields and found to reduce population of $A$. tubercularis. For instance, during a trial aimed at suppressing white mango scale on mango trees in El-Beheira Governorate of Egypt, Abo-Shanab (2012) reported that Super Masrona oil ${ }^{\circledR}$ 95\%, CAPL2 oil ${ }^{\circledR} 96.62 \%$ and Diver oil ${ }^{\circledR} 97 \%$ products could reduce the population of this pest by 90.15\%, 93.55\% and 95.43\% respectively (Figure 5). Mendoza-Montero et al. (2017) also reported up to $98 \%$ mortality of white mango scale when sprayed with mineral oil. On other scale insects, Sun spray $6 \mathrm{E}$ Plus (mineral based product) was found to be highly effective on controlling Pulvinaria innumerabilis and Asterolecanium variolosum (Baxendale and Johnson, 1990). Also, positive results (up to $99.5 \%$ reduction compared to untreated control) were reported by Sadof and Sclar (2000) when using oil-based products to control euonymus scale (Unaspieuonymi) on Japanese pachysandra (Pachysandra terminalis). These 
products kill the scale insects by penetrating their waxy cover and smothering them (Sadof and Sclar 2000). The knowledge about the lifecycle of the scale insects is very important in knowing when to make the applications of these oil products. Also, these oils should be used with caution to avoid harming trees at high concentrations and should be sprayed after picking of fruits and not during flowering or during periods of excessive heat or drought.

Though effective and heavily relied on by farmers to offer instant solution to the scale insect pests, some of these synthetic chemicals are very toxic to both human and other beneficial organisms. Some of these products are either banned for use or allowed as a restricted use product by international governing bodies. For instance, lambda-cyhalothrin, methidathion, bifenthrin and omethoate have quite low $\mathrm{LD}_{50}$ values $(<2,000 \mathrm{mg} / \mathrm{kg})$ that should be avoided if possible (Table 1).This could be evidenced by the number of countries that have banned the use of such products, respectively, 28, 33, 2, 31 (Table 1). In terms of environmental health, products with negative impacts on non-targeted beneficial insects should be avoided as well- broadly; pesticide selection should prioritize those products with relatively lower Environmental Impact Risk Quotient (EIQ) values. used as summarized in the pesticide training tool by Otieno (2019) other human health protection procedures should be to help minimize health risk; always wear protective clothing (gumboots/well fitted shoes, overalls, rubber gloves, breathing masks and eye goggles) and follow the instructions provided on the product label (e.g. rates, time of application and pre-harvest intervals).

Highest efficacy reported (\%)

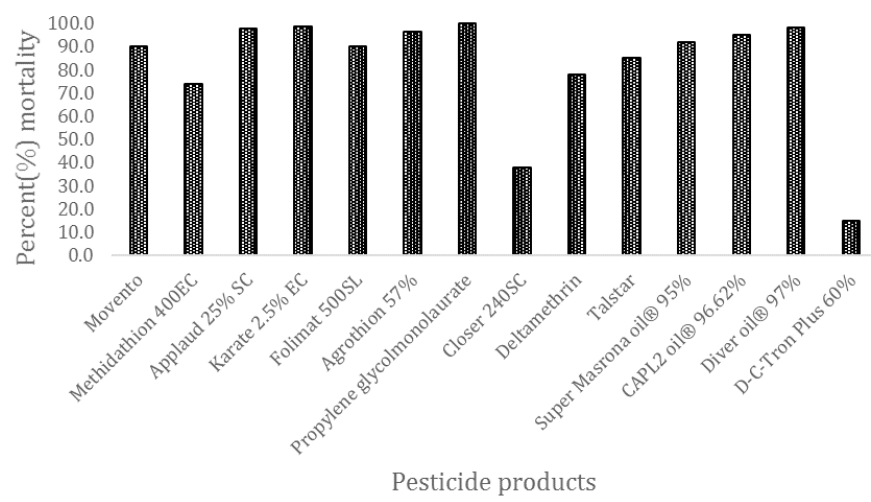

Figure 5: Efficacy comparison; the percentage mortality of white mango scale pests as affected by different pesticides under wide range conditions.

Though there is no evidence of pesticide resistance reported, precautionary measures are necessary to avoid this risk; pesticides should be rotated based on their mode of action (MoA) (as given in the Insecticide Resistance Action Committee, IRAC system) every 1-2 months of applications. From the research, the listed products fall into six groups based on their mode of action- namely UNE, 1B, 3A, 4C, 16, and 23 (Table 1). To implement the pesticide rotation program, all products with similar IRAC-MoA class should not follow each other in the program.

Table 1: Summary of active ingredients, acute oral LD50 values, and environmental impact quotient (EIQ) of selected widely recommended pesticides for the management of $A$. tubercularis pest.

\section{Pesticide product}

Movento

Methidathion 400EC

Applaud 25\% SC

Karate $2.5 \%$ EC

Folimat 500SL

Agrothion 57\%

Propylene glycol monolaurate

Closer 240SC

Deltamethrin

Talstar

Super Masrona oil ${ }^{\circledR} 95 \%$

CAPL2 oil ${ }^{\circledR} 96.62 \%$

Diver oil ${ }^{\circledR} 97 \%$

D-C-Tron Plus 60\%

\section{Active ingredient}

Spirotetramat

Methidathion

Buprofezin

Lambda-cyhalothrin

Omethoate

Malathion

Propylene glycol monolaurate

Sulfoxaflor

Deltamethrin

Bifenthrin

Mineral oil

Mineral oil

Mineral oil

Mineral oil
IRAC MoA

23

$1 \mathrm{~B}$

16

$3 \mathrm{~A}$

$1 \mathrm{~B}$

$1 \mathrm{~B}$

UNE

4C

$3 \mathrm{~A}$

$3 \mathrm{~A}$

UNE

UNE

UNE

UNE
Acute oral LD $_{50} \mathrm{~m}$ kg

$>2,000$

25-54

$>2,000$

925

40

$>5,000$

$>36,000$

$>5,000$

$>2,000$

632

na

na

na

$>2,000$
EIQ

35.29

32.67

$34.97 \quad 0$

$44.17 \quad 28$

na 31

23.832

na 0

na 0

$28.38 \quad 0$

$44.35 \quad 2$

30.090

30.090

30.090

30.090

March 2021 | Volume 34 | Issue 1 | Page 233 
For sustainable control of $A$. tubercularis insect pest, integrated pest management strategies must be adopted throughout the production period. Proper field selection and adoption of tolerant varieties such as Apple and Keit varieties provide an important basis in fighting the impact of white mango scale pests. Routine crop management practices such as annual pruning after the harvesting season to open up the canopy and timed pruning of infested twigs to reduce the population of the pest should be maintained. Chemical compounds should only be used when the infestation is considered high especially towards the fruit development stage to enable production of blemish-free fruits. These products should be less toxic and with low impact risk quotient values. The health risks of these chemicals are further reduced through the use of personal protective equipment during application. The products should also be friendly to naturally occurring enemies (predators and parasitoids) that offer sustainable control of white mango scale pests. From this research, the following research gaps could be prioritized for better management of white mango scale pest:

1. Evaluation of effective and less toxic chemical products for wide and sustainable management of white mango scale pest. This should be a continuous process ensuring mango farmers are constantly in supply with less toxic and environmentally friendly chemicals.

2. Assessment and determination of white mango scale economic injury levels and control thresholds as influenced by agro-ecological zones prevailing in Sub-Saharan Africa. This could give a better prediction and control of the pest.

3. Toxicity and efficacy evaluation of cultural methods currently practiced by the resource constrained mango farmers. This should aim at proving the safety of using these products.

\section{Novelty Statement}

The present investigation shed light on the status of Aulacaspis. tubercularis pest in Sub-Saharan Africa by looking at the pests life cycle, current distribution, impact, and integrated pest management practices for adoption. It also highlights vital themes and questions for future research.
Otieno H.M.O. conceived the research theme, researched and developed the complete manuscript.

\section{Funding}

Not applicable

\section{Conflict of interest}

The author has declared no conflict of interest.

\section{Availability of data and materials}

Not applicable

\section{Consent for publication}

The author confirms that the content of the manuscript has not been published, or submitted for publication elsewhere.

\section{Ethics approval and consent to participate}

Not applicable

\section{References}

Abo-Shanab, A.S.H., 2012. Suppression white mango scale, Aulacaspistubercularis Newstead (Hemiptera: Diaspididae) on mango trees in El-Beheira Governorate, Egypt. Acad. J. Biolo. Sci., 5(3): 43-50. https://doi.org/10.21608/ eajbsa.2012.13870

Anjulo, T.M., 2019. Perception of Ethiopian mango farmers on the pest status and current management practices for the control of the white mango scale, Aulacaspis tubercularis (Homoptera: Diaspididae). J. Adv. Agric., 10: 1846-1852. https://doi.org/10.24297/jaa. v10i0.8431

Arias de L.M., C.A. Jines, C. Carrera, N. Bustos, M. Plúas and K. Gutiérrez. 2004. Biology, population dynamics, sampling, level of damage and alternatives for the management of Aulacaspis tubercularis in export mango. National autonomous institute of agricultural research. Technical brochure No. 56. Guayaquil, Ecuador. pp. 19.

Arysta Life Science, 2011. Product label data sheet: Folimat $800 \mathrm{SL}$ product msds. Availbale at http://arystalifescience.co.za/files/Folimat800-SL_msds.pdf

Ayalew, G., A. Fekadu and B. Sisay. 2015. Appearance and chemical control of white 
mango scale (Aulacaspis tubercularis) in central Rift Valley. Sci. Technol. Arts Res. J., 4(2): 5963. https://doi.org/10.4314/star.v4i2.8

Babege, T., Haile, B., and Hailu, A., 2017. Survey on distribution and significance of White Mango scale (Aulacaspis tubercularis) in Bench-Maji Zone, Southwest Ethiopia. J. Hortic. For., 9(4): 26-32. https://doi.org/10.5897/JHF2016.0474

Bakr,R.F., R.M.Badawy,S.F.Mousa,L.S.Hamooda and S.A.Atteia.2009. Ecological and taxonomic studies on the scale insects that infest mango trees at Qaliobiya governorate. Egypt. Acad. J. Biol. Sci. A, Entomol., 2(2): 69-89. https://doi. org/10.21608/eajbsa.2009.15430

Bakry, M.M., and Tolba, E.F., 2018. Relationship between the population density of the white mango scale insect, Aulacaspis tubercularis (Newstead) (Hemiptera: Diaspididae) and the yield loss of mango trees in Luxor Governorate, Egypt. J. Phytopathol. Pest Manage., pp. 14-28.

Bautista-Rosales, P.U., Ragazzo-Sánchez, J.A., Calderón-Santoyo, M., Cortéz-Mondaca, E., and Servín-Villegas, R., 2013. Aulacaspis tubercularis Newstead in mango orchards of Nayarit, Mexico, and relationship with environmental and agronomic factors. Southw. Entomol., 38(2): 221-231. https://doi. org $/ 10.3958 / 059.038 .0207$

Baxendale, R.W., and W.T. Johnson. 1990. Efficacy of summer oil spray on thirteen commonly occurring insect pest. J. Arboric., 16: 89-94.

Bezu, T., K. Woldetsadik and T. Tana. 2015. Production scenarios of mango (Mangifera indica L.) in Harari regional state, Eastern Ethiopia. Sci. Technol. Arts Res. J., 3(4): 59-63. https://doi.org/10.4314/star.v3i4.8

Borchsenius, N.S., 1966. A catalogue of the armored scale insects (Diaspididae) of the world. (In Russian.) Nauka, Moscow, Leningrad, Russia, pp. 449.

CABI, 2019. Invasive species compendium. Wallingford, UK: CAB International. www. cabi.org/isc.

Camacho, E.R. and J.H. Chong. 2015. General biology and current management approaches of soft scale pests (Hemiptera: Coccidae). J. Integr. Pest Manage., 6(1): 17. https://doi. org/10.1093/jipm/pmv016

Daneel,M.S. and S. Dreyer.1997. Further studies on the establishment Aphytis sp. and Cybocephalus binotatus in mango orchards for the control of the mango scale. Yearbook-South Afri. Mango Growers Assoc., 17: 144-146.

Dessalegn, Y., H. Assefa, T. Derso and M. Tefera. 2014. Mango production knowledge and technological gaps of smallholder farmers in Amhara region, Ethiopia. Am. Sci. Res. J. Eng. Technol. Sci. 10(1): 28-39.

Djirata, O., 2017. Bionomics and management of white mango scale, Aulacaspis tubercularis newstead (Homoptera: Diaspididae) in Western Ethiopia, and Central and Eastern Kenya (Doctoral dissertation, Addis Ababa University).

Djirata, O., E. Getu and R. Kahuthia-Gathu. 2016. Trend in mango production and potential threat from emerging white mango scale, Aulacaspis tubercularis (Homoptera: Diaspididae) in central and Eastern Kenya. J. Natl. Sci. Res., 7(6): 87-94.

Djirata, O., E. Getu and R. Kahuthia-Gathu. 2019. A survey of geographical distribution and host range of white mango scale, Aulacaspis tubercularis Newstead (Hemiptera: Diaspididae) in Western Ethiopia. J. Entomol. Nematol., 11(5): 59-65.

Duressa, T.F., 2018. Newly emerging insect pests and diseases as a challenge for growth and development of Ethiopia: The case of western Oromiya. J. Agric. Sci. Food Res., 9: 201.

Eshenaur, B., J. Grant, J. Kovach, C. Petzoldt, J. Degni and J. Tette. 2019. Environmental impact quotient: A method to measure the environmental impact of pesticides. New York state integrated pest management program, cornell cooperative extension, Cornell University. $1992-2019$.

Extension Toxicology Network- (EXTOXNET). 1993. Methidathion. Available at http://pmep. cce.cornell.edu/profiles/extoxnet/haloxyfopmethylparathion/methidathion-ext.html

Fita, T., 2014. White mango scale, Aulacaspis tubercularis, distribution and severity status in East and West Wollega Zones, western Ethiopia. Sci. Technol. Arts Res. J., 3(3): 1-10. https://doi.org/10.4314/star.v3i3.1

FAO, 2019. Food and Agriculture Organization of the United Nations- FAO. 2019. FAO Specifications and Evaluations for Agricultural Pesticides. Available at http://www.fao.org/ fileadmin/templates/agphome/documents/ Pests_Pesticides/ 
Griesbach, J., 2003. Mango growing in Kenya. World agroforestry centre. Available at http:// www.worldagroforestrycentre.org/

Halteren, P.V., 1970. Notes on the biology of the scale insect Aulacaspis mangiferae Newst. (Diaspididae, Hemiptera) on mango. Ghana J. Agric.Sci.,3(2):83-85.Available at https://www. cabdirect.org/cabdirect/abstract/19720503616

Hamdy, N.M., 2016. Some ecological aspects on mango white scale, Aulacaspis tubercularis and associated natural enemies infesting mango trees in Qalyubiya Govrnorate [(Hemiptera: Sternorrhyncha: Diaspididae)]. J. Plant Prot. Pathol., 7(6): 377-383. https://doi. org/10.21608/jppp.2016.50595

Heriberto N.-C.D., M.A. Urias-Lopez, J.A. Gonzalez-Carrillo and G. Lopez-Guillen. 2016. Seasonal abundance of white mango scale, Aulacaspis tubercularis newstead, in Guerrero, Mexico. Southw. Entomol., 41(3): 845-853. https://doi.org/10.3958/059.041.0326

Heriot, A.D., 1934. The renewal and replacement of the stylets of sucking insects during each stadium, and the method of penetration. Can. J. Res., 11: 602-612. https://doi.org/10.1139/ cjr34-117

Hernández-Fuentes, L.M., M.A. Urías-López, A. López and A. López. 2012. Use of attractants and nutritional supplements to increase mango white scale's, Aulacaspis tubercularis Newstead (Hemiptera: Diaspididae) predators. Acta Zool. Mexicana, 28(1): 145-160.

Hodges, G., and A. Hamon. 2016. White mango scale, Aulacaspis tubercularis newstead (Coccoidea: Diaspididae). pest alert, Florida department of agriculture and consumer services, pest alert division of plant industry, pest alert. Available at https://www.fdacs.gov/ content/download/67879/file/

Infonet-Biovision: Crops fruits and vegetables mango. Available at https://www.infonetbiovision.org/PlantHealth/Crops/Mango

Johnson, W., 1999. Final report on the safety assessment of Propylene Glycol (PG) Dicaprylate, PG Dicaprylate / Dicaprate, PG Dicocoate, PG Dipelargonate, PG Isostearate, PG Laurate, PG Myristate, PG Oleate, PG Oleate SE, PG Dioleate, PG Dicaprate, PG Diisostearate, and PG Dilaurate. Int. J. Toxicol., 18(2_suppl): 35-52. https://doi. org/10.1177/109158189901800207
Juárez-Hernández, P., J. Valdez-Carrasco, G. Valdovinos-Ponce, J.A. Mora-Aguilera, G. Otero-Colina, D. Téliz-Ortiz and V.A. González-Hernández. 2014. Leaf penetration pattern of Aulacaspis tubercularis (Hemiptera: Diaspididae) stylet in Mango. Florida Entomol., 97(1): 100-108. https://doi. org $/ 10.1653 / 024.097 .0114$

Kameri, V., 2012. Factors that affect production and marketing of mangoes in Kenya: A case of Maragua ridge location in district of central province (Doctoral dissertation). Available at https://ir-library.ku.ac.ke/ handle/123456789/3621?show

Kovach, J., C. Petzoldt, J. Degni and J. Tette. 1992. A method to measure the environmental impact of pesticides. New York's Food Life Sci. Bull., 139: 1-8.

Labuschagne, T.I., H.V. Hamburg and I.J. Froneman. 1995. Population dynamics of the mango scale, Aulacaspis tubercularis (Newstead) (Coccoidea: Diaspididae), in South Africa. Isr. J. Entomol., 29: 207-217

Le Lagadec, M.D., 2002. The control of mango scale in commercial Orchards through the use of the predatory beetle, Cybocephalus binotatus. VII Int. Mango Symp., 645: 509-515. https:// doi.org/10.17660/ActaHortic.2004.645.67

Malumphy, C., 2014. An annotated checklist of scale insects (Hemiptera: Coccoidea) of Saint Lucia, Lesser Antilles. Zootaxa, 3846(1): 6986. https://doi.org/10.11646/zootaxa.3846.1.3

Mani, M., and A. Krishnamoorthy. 1998. Studies on the natural enemies of the mango scale, Aulacaspis tubercularis Newstead (Diaspididae, Homoptera). Paper presented in the national symposium on mango production and export, Lucknow. June 25-27.

Mendoza-Montero, M.A., L.M. HernándezFuentes, S. Ramírez-Alarcón and J.F. SolísAguilar. 2017. Toxicity of insecticides on white scale (Aulacaspis tubercularis Newstead) (Hemiptera: Diaspididae) of mango (Mangifera indica L.). Agroproductividad, 10(3): 19-23.

Michael, D.W., M. Tsegay and H. Lemma. 2014. Pest management decision guides: Mango scale on mango- Ethiopia. 2014 pp. 1. Cabi. Available at https://www.cabdirect.org/cabdirect/ abstract/20157800479

Moharum, F.A.E., 2012. Description of the first and second female and male instars of white 
mango scale Aulacaspis tubercularis Newstead (Coccoidea: Diaspididae). J. Basic Appl. Zool., 65(1): 29-36. https://doi.org/10.1016/j. jobaz.2012.02.003

Mossler, M.A. and O.N. Nesheim. 2004. Tropical fruit pest management strategic plan (PMSP). EDIS, 2004(5). Available at https://ufdcimages. uflib.ufl.edu/IR/00/00/42/89/00001/PI06200. pdf.

Mulinge, W.K., 2015. Factors influencing grafted mango (Mangifera indica L.) production in Matinyani division, Kitui County (Doctoral dissertation).

Neguse,T.B., F.K.Wanzala,W.M.Ali,W.O.Owino and G.S. Mwangi. 2019. Mango (Mangifera indica L.) production practices and constraints in major production regions of Ethiopia. Afr. J. Agric. Res., 14(4): 185-196. https://doi. org/10.5897/AJAR2018.13608

Ngethe, E., V. Gitonga, A. Gachuiri, S. Carsan, K. Kehlenbeck and S. McMullin. 2019. Mango planting manual. Available at www. worldagroforestry.org.

Northern Territory Government of Australia. 2019. Delivering mango technology: Managing mango scale managing mango scale- p. 1. Available at https://dpir.nt.gov.au/_data/ assets/pdf_file/0018/228015/mango_scale_ management_poster.pdf.

Ofgaa, D., G. Emana and R. Kahuthia-Gathu. 2018. Population dynamics of white mango scale, Aulacaspis tubercularis Newstead (Hemiptera: Diaspididae) in Western Ethiopia. Afr. J. Agric. Res., 13(31): 1598-1605. https:// doi.org/10.5897/AJAR2018.13176

Ofgaa, D.J. and D.G. Emana. 2015. Infestation of Aulacaspis tubercularis (Homoptera: Diaspididae) on mango fruits at different stages of fruit development, in western Ethiopia. J. Biol. Agric. Healthc., 5: 34-38.

Otieno, H.M.O., 2019. Pesticide training tool: A simplified guide for agricultural extension officers and farmers. Asian J. Res. Crop Sci., 3(4): 1-5. https://doi.org/10.9734/ajrcs/2019/ v3i430056

Peña,J.E., M. Aluja and M. Wysoki. 2009. Pests, In: R.E. Litz [ed.], The Mango: Botany, production and uses (2nd ed.). CAB Intl. pp. 317-345. https://doi.org/10.1079/9781845934897.0317

Pesticide Action Network International, (PAN). 2019. International consolidated list of banned pesticides $-4^{\text {th }}$ edition. Available at http:// pan-international.org/pan-internationalconsolidated-list-of-banned-pesticides/

Rehmat, T., S.B. Anis, M.T. Khan, J. Fatma and S. Begum. 2011. Aphelinid parasitoids (Hymenoptera: Chalcidoidea) of armoured scale insects (Homoptera: Diaspididae) from India. Biol. Med., 3(2): 270-281.

Sadof, C.S. and D.C. Sclar. 2000. Effects of horticultural oil and foliar- or soil-applied systemic insecticides on euonymus scale in pachysandra. J. Arboric., 96: 120-125.

Sadof, C.S. and J.J. Neal. 1993. Use of host plant resources by the euonymus scale, Unaspis euonymi (Homoptera: Diaspididae). Ann. Entomol. Soc. Am., 86(5): 614-620. https:// doi.org/10.1093/aesa/86.5.614

Salem, H.A., K.H. Sabry and N.B. Aref. 2011. Evaluation the activity of certain insecticidal, time and number of application in controlling white mango scale, Aulacaspis mangiferae (New.) in mango orchards. Bull. NRC, 36: 271-286.

Salem, H.A., Y.A. Mahmoudand and I.M.A. Ebadah. 2015. Seasonal abundance, number of generations and associated injuries of the white mango scale, Aulacaspis tubercularis (Mangifera) (Newstead) (Homoptera: Diaspididae) attacking mango orchards. Res. J. Pharm. Biol. Chem. Sci., 6(4): 1373-1379.

Sayed, A.M.M., 2012. Influence of certain bioagents and climatic changes on the population density of the white mango scale insect, Aulacaspis tubercularis Newstead. Egypt. J. Agric. Res., 90(2): 607-624.

Senasica, 2009. Servicio nacional de sanidad, inocuidady calidad agroalimentaria. Secretaría de agricultura, ganadería, desarrollo rural, pesca y alimentación. campaña de manejo fitosanitario del mango en el estado de guerrero.

Syngenta Company, 2014. Product safety data sheet-Karate 2.5 EC. Available at https:// www.syngenta.com.vn/sites/g/files/zhg.531/f/ thong20tin20an20toan_karate202.5ecmsds_0. pdf? token $=1495094512$

Terefe, T.H., S. Tsegaye and T. Wakuma. 2014. White mango scale insect's infestations and its implications in guto gida and digadistrcts of East Wellega Zone. ABC Res. Alert, 2(2). https://doi.org/10.18034/abcra.v2i2.287

Teshale, D.D., H.T. Tesfaye, W. Belay and T.E. Tariku. 2019. Distribution and population 
dynamics of the white mango scale, Aulacaspis tubercularisin Southwest Ethiopia. Agric. Res. Tech. Open Access J., 20(1): 556117.

The Insecticide Resistance Action Committee (IRAC). 2019. IRAC mode of action classification scheme. Issued, June 2019. Version 9.3. Available at https://www.irac-online.org/

Urías-López, M.A., J.A. Osuna-García, V. Vázquez-Valdivia and M.H. Pérez-Barraza. 2010. Population dynamics and distribution of the white mango scale (Aulacaspis tubercularis Newstead) in Nayarit, Mexico. Revista Chapingo. Ser. Hortic., 16(2): 77-82. https:// doi.org/10.5154/r.rchsh.2010.16.009

Van Halteren, P., 1970. Notes on the biology of the scale insect Aulacaspis mangiferae Newst. (Diaspididae, Hemiptera) on mango. Ghana J.
Agric. Sci., 3: 83-85.

Viljoen,H.M., and E.A.Villiers.1987.Effectiveness of fenvalerate and monocrotophos against the mango scale, Aulacaspis tubercularis Newstead. Inf. Bull. Citrus Subtrop. Fruit Res. Inst., South Afr., 173: 19-23.

Walum, E., 1998. Acute oral toxicity. Environ. Health Perspect., 106 (Suppl. 2): 497-503. https://doi.org/10.1289/ehp.98106497

World Health Organization (WHO). 2019. International programme on chemical safety. Available at https://www.who.int/

Yeshitila, T. and T. Nessel. 2003. Characterization and classification of mango ecotypes grown in Eastern hararghe (Ethiopia). Sarhad J. Agric., 19(2): 1-2. 